ANNA LAPUTKO,

Bogomolets National Medical University (Kyiv, Ukraine)

e-mail: belogortseva@ukr.net, ORCID:0000-0002-7501-500X

\title{
THE CONCEPT OF HUMAN DIGNITY AS A BASIS FOR COOPERATION OF THE CATHOLIC CHURCH WITH STATE AND PUBLIC ORGANIZATIONS
}

\begin{abstract}
The article investigates the understanding of the concept of human dignity in the Catholic social doctrine and secular legal declarations aimed at the protection of personality rights. It is shown that notwithstanding the essential basic prerequisites, the concept of human dignity is foundational for the solution of new social problems. Consequently, human dignity is a basis for a fruitful dialog between the Catholic Church and world in order to create the society of peace, respect and well-being. It is proved that the turn to the systematic use of human right language and the strategies of the protection of human dignity occurred during the Second Vatican Council. This process is a part of the anthropological turn of the Christian religion within the global transformations of religious worldview in the age of late modern and postmodernism. Refreshment of the social teaching of Catholicism occurs within the last encyclical "Fratelli tutti" by the Pope Francis. The principle of the absolute value of human dignity becomes primary for the social teaching of the "Fratelli tutti" encyclical by the Pope Francis. This principle is fully substantiated. The Pope recognize that the absoluteness of human dignity is not obvious for the contemporary social discourse, the personality is more and more reduced to the individual who can be manipulated destroying the natural context of life which for the individual have always been communities. The Pope provides arguments about the dignity of the individual, which are revealed through faith, love, reflection and social dialogue.
\end{abstract}

Key words: human dignity; Catholic Church; the image of God; documents of the Second Vatican Council; the Universal Declaration of Human Rights.

\section{Introduction}

We can consider the substantiation of the provisions on human dignity a foundation stone of the anthropological turn carried out by the Christian religion. Based on the assertion that man is the image and likeness of God, the Christian religion has declared that every human, solely by his or her belonging to the human race, without any additional achievements, is the pinnacle of God's creation and is equal in the family of other equals. The stated above was taken as a basis for Christian social doctrines in general and in particular the Social doctrine of the Catholic Church. It determines us to think about human absolute equality before God, notwithstanding the descent of a human, his or her cultural environment, moral priorities, worldview preferences.

The UN Charter the Universal Declaration of Human Rights (1948) also emphasizes on the weight of human dignity awareness as a basis of human rights. Definitely, the stated charter has no reference to the understanding a human being as the image of God. However, regardless of the fact that secular law and the documents of the Catholic Church are based on different basic assumptions of the understanding of a human, they have common views on the importance of human dignity. This suggests the relevance of this subject in the modern world where the mottos of human equality and dignity are declared in contrast to their numerous and severe violations.

ISSN 1728-9343 (Print)

ISSN 2411-3093 (Online)
The purpose of this article is to research the possibility of the fruitful cooperation of the Catholic Church and government institutions in the context of the solution of the newest challenges of modernity based on the understanding of human dignity. The basic resources of our study are the documents of the Catholic Church, the encyclicals of Pope Francis, Benedict XVI, the study of theologians and legal documents on the need to develop a culture of dialogue between religion and the world.

\section{Research methods.}

Studying the ideas of the social doctrine of Catholicism and the practices of their application requires the wide use of the instruments of modern hermeneutics and social analysis in their theological interpretation.

\section{Results and Discussion}

In catholic social doctrine, the problem of dignity is considered in a wide range of problems of modern world from human conception to his/her transition to afterlife. Thus, the topical issues of modernity are the value of human life in the context of both abortions and euthanasia problem; decent standard of living of disabled people; problems of global social and economic disparity etc.

The Catechism of the Catholic Church states that "human life must be respected and protected absolutely from the moment of conception" (Catechism of the Catholic Church, art. 2270). Fundamental documents of SKHID Vol. 1 (1) January-February 2021 
the Catholic Church concordant with international legal document declare that human rights to dignified life are considered universal, unbreakable and indefeasible. In particular, at the Second Vatican Council it was proclaimed that "...everything that violates the value of the human person, such as mutilation, torture inflicted on the body and soul, violence in the direction of mental coercion; everything that degrades human dignity (...), everything and similar deeds and practices are something shameful; denies human civilization, it is a disgrace to those who are allowed to do more than those who are offended, and it is most contrary to the honor of the Creator". (Documents of the Second Vatican Council, 1996: 528).

According to the main purpose of II Vatican Council "modernization" (aggiornamento) of Church, in the text of Gaudium et spes Constitution the change of the approach of the Catholic Church to coexistence with modern world is reflected. As opposed to the previous documents of the Church, which were primarily based on the dogmatic foundations given in the Revelation, the stated document is based on the analysis of the components of social life such as culture, family, politics, war and peace, society, economics etc. Thus, the new approach consists in the understanding of the fact that "a human first lives in this world, faces certain problems in various world issues, and only then needs to illuminate these problems with the light of the Gospel. In addition, this approach emphasizes that the Church of Christ is His Body, that is, that God came into this world, incarnated, because he loved this world, took on all the affairs and worries of this world, and even then enlightened this world with his Word, transforming it" (Balog, 2020).

The Gaudium et spes constitution, is by far a weighted document in which the attempt was made to express the position of the church with regard to all forms of social life so that this document was a guidebook to solve complicated issues of modernity on the basic foundations of Christianity. Despite the fact that, in the meantime, this document has not escaped criticism and "even within a particular state with a relatively balanced situation between denominations, there is criticism of the Catholic Church and its social teaching, which changed the prospect of God's grace and prosperity in the secular world" (Balog, 2020), this document is still basic for revealing the position of the Church in the modern world. Professor P. Yarotskyi described the stated change as follows: "The theology of salvation gives way to the theology of the preservation of creation. Eschatological theology of human existence in the afterlife is replaced by the innovative theology of sustainable human development in the afterlife, the real world of existence" (Yarotskyi, 2011: 8).

Thus the foundation on which the social teaching of the Catholic Church is built after the Second Vatican Council is anthropology (Havrylyuk, 2013). The solution of social problems is seen through the perception of a human a central subject of social relations which suggests that social teaching of Catholicism is anthropocentric and its key category is human dignity. Emphasizing the necessity to respect human dignity, the value of his/her life sounds in numerous post-conciliar encyclicals. In particular, in the encyclical of Leo XIII "Rerum Novarum" (1891) it is noted that the dignity of the human "spirit" is "that which bears the image and likeness of God". The pontiff emphasizes that "It contains the supremacy in virtue, which gives a human the right to possess lower creatures and to promote all lands and seas for the benefit of a human...., nor can anyone stand in the way of human perfection, which is aimed at obtaining eternal life. What's more: no human has the right to deny respect for himself or herself by nature and to accept the bondage of the spirit, for it is not a question of the rights to which freedom belongs, but of the rights of God which are absolutely inviolable" (Pope Leo XIII, 2015). Thus, dignity is a fundamental feature of a human, which ensures the equality in all forms of his/her being. In theology of Pius XII the understanding of human dignity obtains the status of a formalized doctrinal basis of the Catholic theory of human rights. The concept of dignity is continued and developed in the works of John XXIII, Paul VI and John Paul.

Undoubtedly, the social factors in the development of human dignity were the social upheavals of the twentieth century, which exacerbated the value of the human person. Because, as Paul VI noted, from the eternal and historical meaning of the dignity of the human person can be deduced the practical meaning of the concept of the common good of human communities (Havrylyuk, 2013). But the problems of modernity, in a society that, at first glance, has reached the level of developed legal humanism, the constant emphasis on the dignity of human nature has not lost its relevance. The words of Pius XII, which he addressed to the society of the early twentieth century are relevant to the current state of the international community: "We can barely keep our pens at the thought of the countless troubles of those people who have so far enjoyed some well-being in their home environment, at least limited and modest. Our Father's soul is filled with the greatest sorrow in anticipation of all that will arise from the gloomy seed of violence and hatred, to which the sword is already making bloody furrows. But it is in view of the bitterness of so many misfortunes that are looming and in fear of what will happen in the future that we consider it our duty to direct more and more the eyes and souls of all who have preserved an honest will to the One Who alone gives salvation to the human race; to the One Whose merciful and omnipotent hand can put an end to this storm; to the One, at last, Whose Truth and Love can enlighten the minds and correct the decisions of people who are obsessed with the flow of mistakes, the heat of excessive selfishness, and almost drowning in waves of discord and struggle" (Pope Pius XII, 2021).

Despite meaningful religious and international legal instruments on the recognition of the right and protection of human dignity, the modern world is far from a state of common prosperity and is full of conflicts both in third world countries and in developed countries. One of the acute problems now facing the European Union due to hostilities in the Middle East and also Ukraine due to the war in the East is mass migration, in which people are often unprotected both physically and psychologically. In the context of the Middle East, the problem of migration is closely linked to the problem of human trafficking, as migration takes place over long distances and often outside the law. The reason for illegal migration is often the inability and unwillingness of the European Union to accept large flows of refugees. But, even if a person is legally granted refugee status, he or she is in a state of anxiety and stress due to the new cultural and social circumstances in which he or she has to start a new life. 
The stated problem is the plane of practical implementation of the program documents on human dignity and the right to a dignified life. The Catholic Church emphasizes the need for states to be aware of their responsibility for the dignity and lives of people and to educate their faithful in openness to refugees, emphasizing that this is an absolutely Christian quality. The head of the German Catholic bishops, Archbishop of Munich Reinhard Marx, remarks: "If we do not come to the rescue, if we build a wall and continue to allow people to drown and suffocate on our borders, it will really endanger Christian Europe" (Strack, 2015). The archbishop draws attention to the threats in such a situation and emphasizes that the Christian identity of the European continent may be in danger.

The Catholic Church, in agreement with the governments of European countries, provides asylum to refugees in both monasteries and church premises, in response to Pope Francis' call for each monastery in Europe to receive one refugee family.

We emphasize that the Catholic Church's position on refugees is based on a general understanding of "humanitarian activities to save lives, organize medical and legal care, housing, food, education and, in general, the integration of refugees into host societies" (Vasilevich, 2019).

The stated above indicates a practical manifestation of respect for human dignity, its affirmation by the Catholic Church. Archbishop Marx's assessment of the current situation is correct, not only as a political and social challenge, but also, first of all, as a challenge to Christian Europe: "The refugee problem can change the church. But the willingness to accept and support refugees is an integral part of the genetic identity of Christianity. And Europe to still be Christian" (Vasilevich, 2019). Thus, the issue of refugees for the church is a matter of values.

Naturally, there is a direct connection between social and anthropological dimensions of life. Emphasizing the preservation of Christian Europe, it is necessary to realize that the concept of "Christian Europe" is first of all a human being a Christian and only then the social programs of the church. Prophetic in this aspect is the encyclical of Pope Francis "Light of Faith", which in general has a humanistic and anthropological character (Pope Francis, 2013). The Encyclical emphasizes that the church must restore the faith of light. This is the light that is meant to illuminate all human life. And this is the light that is a signpost for the Christian man, which "brings us out of our closed up "ourselves" to the boundless spaces of life together" (Pope Francis, 2013, art. 4).

It should be noted that the problems of refugees have exacerbated the problem of the "nominal Christian" and the "real Christian". It is known that state and church programs to help refugees are often exposed in many countries and active public resistance. And in this respect, in the Encyclical, Pope Francis warns that a person who "closes up isolates himself or herself from the Lord and from his or her neighbors; which makes his or her life empty and his or her affairs fruitless like a tree growing far from the water" (Pope Francis, 2013, art.19).

In the context of the latest social challenges, Pope Francis, "continuing the line of love theology begun by Benedict XVI", speaks of God as perfect Love and points to its decisive ability to change the world and man. "In the light of faith combined with love, Francis finds a way to serve justice, law and peace" (Havrylyuk, 2015: 220224).

From the above, the active position of the church on the harmonization of academic and practical theology becomes clear. By proclaiming and interpreting higher truths, the Church embodies them in everyday life and is often at the forefront of solving anthropological and social problems. This is stated in "Rerum Novarum": "Finally, the Church is not satisfied only with pointing to the means of salvation, but also touches them with her motherly hand. For it is all directed to educate and form people on this basis, trying to make the waters of the salvation of her teaching flow widely through bishops and priests to flood the whole earth" (Pope Leo XIII, 2015).

Thus, the basic principle of the Church's social service is the principle of subsidiarity, according to which individuals, organizations and structures of civil society, including churches, can solve social problems more effectively than state and interstate political organizations (Vasilevich, 2019).

Of course, the Catholic Church does not ignore the social problems of Ukrainian society. Here we see the continuation of the integral line of the Catholic Church after the Second Vatican Council. Among the wide range of social services, we will highlight those examples that are consistent with the problems of refugees and vulnerable. It is worth noting here that the Catholic Church demonstrates its care for a human from the first steps of his or her life. In particular, at Catholic monasteries in Vinnytsia, Lviv, Ternopil, Kyiv and other cities, as well as at maternity hospitals, hospitals "Windows of Life" were opened and will continue to open for infants abandoned by their parents (Vinnytsia..., 2012). Single mothers are not left out either. In particular, there is a network of social centers for single mothers. The religious mission of the Catholic Church in Ukraine "Caritas-Spes" within the "Hope" project has opened the third such house (Pope Leo XIII, 2015). A rehabilitation center for children from troubled families has been opened. Other social problems are not left out either. Thus, in Zaporizhia at the Catholic monastery created "Men's House of St. Brother Albert" (Piddubna, 2016). It is designed for 30 permanent places for homeless people. There are canteens for the needy, for example, "Dobryi Khlib" (Good Bread) at the Roman Catholic Church of God the Merciful Father (Havrylyuk, 2020).

The active social work of the Catholic Church led to the significant dissemination of its present in the territory of Ukraine. In particular, "As of January 1, 2019, there are 897 registered and 10 more unregistered communities, 5 fraternities, 41 missions, 111 monasteries with 664 monks, 10 theological schools with 378 students, and 20 periodicals. There are 707 priests of the Latin rite in Ukraine, 346 of whom are foreigners. It should be noted that the results are presented without taking into account the Ukrainian Greek Catholic Church, the Mukachevo Diocese of the Greek Catholic Church and the Armenian Catholic Church in Ukraine (Department, 2019). Among the mentioned communities in Ukraine there are numerous movements and communities such as: the Living Rosary community, the Light-Life movement, including the House Church, Family of Families, Ministers, Scouts, Kolping Family, Knights of Columbus, Legion of Mary, Catholic Action, Neocatechumenal Road, Taizé Community, Franciscan Secular Order, Religious Mission Movement of the Families of Nazareth, the 
Apostolate of the Good Death, the Restoration in the Holy Spirit, the Third Dominican Order and others" (Department, 2019).

The latest popes radically emphasize that today, there are more and more interdependence features in the lives of persons and peoples. Globalization help reduce the meaning of boundaries separating the humanity which becomes one family. Globalized capitalism facilitates the unification of individuals, depreciation of the meaning of a personality. Popes Benedict XVI and Francis emphasize the low efficiency of the dominant economic and political system, which became unalterable after the fall of the communist system. In particular, Pope Francis at the beginning of the last encyclical "All the Brothers" testifies: "As I was writing this encyclical, the Covid-19 epidemic suddenly broke out, showing our illusory security. Despite the different reactions of individual countries, there was an inability to act together. Although we are closely connected, there are differences that have prevented us from solving common problems. If someone thinks that it was about improving what we have already done, or the only conclusion from this situation is to improve the existing systems and rules, he denies the reality" (Pope Francis, 2020: 4). The call for significant changes in modern liberal capitalism and the global order has been characteristic of Catholic teaching since the time of Pope John Paul II. The latter saw that the fall of the communist system did not bring the "end of history", as the new trials and tribulations of liberal capitalism required historical transformations towards a more harmonious society. Pope Benedict XVI emphasized that such a future society must be a "civilization of love". Pope Francis emphasizes that over the last years crisis phenomena increase, achievement of a "civilization of love" becomes more and more estraged. According to Pope Francis, "for decades, the world seemed to have learned the lessons of so many wars and misfortunes and was slowly moving toward various forms of integration. ... But the past repeats itself. Long-standing conflicts are fueled, which, as it seemed, had already been resolved; closed, extremist, full of hatred and aggression, nationalisms are being revived" (Pope Francis, 2020: 6). Indeed, today there is a growing risk of reviving the influence of ideologies of secrecy, national selfishness, various ideologies of confrontation. At the same time, the ideas of openness are monopolized by neoliberal economists (Pope Francis, 2020: 7). At the same time, "local conflicts and neglect of the common good have become tools through which the global economy introduces a model of homogeneous culture" [lbid]. Global problems of modernity generate the necessity to establish a single world government (Pope Francis, 2020: 12) or at least the existence of judicial authority whose decisions would be binding on everyone. But today humanity is increasingly moving away from the world legal order. Pope Francis uses the metaphor of the "third world war" to describe the current situation, which is already under way because there is a network of local conflicts that are manifestations of the general crisis of humanity. "Wars, acts of terrorism, racial and religious persecution and many other abuses against human dignity are assessed differently, depending on whether or not they meet specific interests, mainly economic. The truth is what meets the interests of persons in authority and ceases to be so if it brings no more benefit to them. The number of such cases of violence is painfully increasing in many parts of the world in such forms that it can already be called a gradual third world war" (Pope Francis, 2020: 13). This situation of systemic crisis as a global set of conflicts poses numerous threats to the freedom and rights of personalities, lowers human dignity (Pope Francis, 2020: 12). The very relativism of social sentiments and the reduction of social values exclusively to "market freedom" create a situation where society is easy to manipulate, and Pope Francis analyzes the many political ideologies used as technologies of power today. Authorities at the national and international levels speculate on liberal theories about the need for openness and the free market, as well as various theories about the need for numerous walls. The unifying devaluation of the individual and communities, the construction of new walls against the "others" equally contribute to the disappearance of social justice, solidarity, and then to freedom and human rights. Thus, the pope notes that those who erect walls become slaves to the walls. "Unbelievable, but technical development has not destroyed the fears of the past; moreover, these fears have managed to hide and strengthen behind new technologies. Even today behind the walls of the ancient city there is an abyss, an unknown territory, a desert. What comes from there is not probable, because it is not known, not familiar, does not belong to the settlement. This is the territory of "barbarians", from whom you need to defend yourself in any way. So, new walls are being built for self-defense, and the outside world no longer exists, only "my" world exists, and to such an extent that many people cease to be people with their inalienable dignity and become only "them". The tendency to build a culture of walls is being revived. It is a tendency to build walls in hearts and on earth in order to avoid meeting other cultures, other people. And a builder of walls, deprived of a wider horizon, will eventually become a slave to his walls. Because he lacks this otherness" (Pope Francis, 2020: 13-14). Popes Benedict XVI and Francis constantly emphasize that the world has already become so united that all the inhabitants of the Earth are the closest neighbors. Under these conditions, it is impossible to build any separate "civilizations" that would be separated from the "others". Efforts to build walls are aimed only at transforming individuals and communities into material for social manipulation and exploitation. One can see in the radical critique of "building walls" the defense of the interests of one's own faithful: after all, a significant number of Catholics are among those migrants who are already available in developed countries or want to get there now. However the Catholic Church traditionally depends on those conservative Christians who assert the right to build the national states without the acceptance of the significant number of migrants, in particular to preserve national and religious identity. But Pope Francis neglects such ideas of his faithful, which are very popular in some countries. For him, the main principle is the principle of absolute respect to the dignity of each person and acceptance of migrants seems to be a direct consequence of the efficiency of such principle. The problems generated by migration waves are not discussed in detail. The Pope is convinced that the successful integration of all migrants is possible, in which society will only get richer and more developed. Moreover, only the societies which are open to everyone cane be fruitful in the modern world (Pope Francis, 2020: 19). Accordingly, politicians who argue that migrants should be avoided are condemned as populists (Pope 
Francis, 2020: 17). The Pope declares: "It is unacceptable for Christians to have such a mentality and such an attitude, when sometimes some political preferences prevail over religious beliefs about the inalienable dignity of every human person, regardless of his or her origin, skin color or religion, and the higher law of brotherly love" (Pope Francis, 2020: 18). Thus, the idea of the absolute dignity of the individual is declared as a religious belief, which for Christians should be decisive in their worldview and practice.

\section{Conclusions.}

Thus, modern social problems became a significant challenge for the cooperation between religious and state, public organizations. In this cooperation, the Catholic Church occupies one of the leading positions, following the general line of development of the Church, set by the Second Vatican Council. Despite the fact that at the basic level the secular and Christian understandings of the concept of human dignity differ, the Catholic Church cooperates with state and public organizations in order to protect human dignity. This dialogue can have real results in the solving of problems of human life and development, the creation of more fair and peaceful society. Such cooperation is especially important in the conditions of modern challenges of migration, widening of cultural diversity, contingence of the representatives of various civilization traditions. Ethical acceptance of the other and renewal of the culture of hospitality, formation of a new ethos of brotherhood, struggle for the rights of the socially disadvantaged and search for new formats of social dialogue that would include the voice of religious communities - all this requires broad cooperation of churches, states and public organizations. The recognition of the value of human dignity as main and absolute value became a common ground for the system of cooperation. On this ground, the formation of specific forms of dialogue and cooperation between the church and state (public) institutions addressing the many social needs in Europe is carried out.

\section{REFERENCES}

Balog, P. (2020, December, 12). Tserkva i suchasnyy svit Gaudium et Spes. Retrieved from https://clck.ru/TR52J (in Ukrainian).

Catechism of the Catholic Church (2005). Retrieved from https://www.vatican.va/archive/ENG0015/_INDEX.HTM.

Documents of the Second Vatican Council (1996). - Lviv, 1996 (in Ukrainian).

Havrilyuk, T. (2015). Anthropological aspects in the encyclical of Pope Francis "Lumen Fidei". Ukrainian Religious Studies, 73: 220-224 (in Ukrainian).

Havryliuk, T., Lukashenko, M. (2020). Roman Catholicism in Ukraine: The Contemporary Situation, Social Acceptance, and Social Service. Occasional Papers on Religion in
Eastern Europe: 40 (3), Article 5. Retrieved from https://digitalcommons.georgefox.edu/cgi/viewcontent.cgi?art icle $=2174 \&$ context=ree

Havrylyuk, T.V. (2013). Catholic anthropologism in the context of socio-cultural realities of Ukraine. Ukrainian Religious Studies, 66: 390-398 (in Ukrainian).

Piddubna, O. (2016). Men's house of St. Brother Albert; a place where people are seen in homeless people Retrieved from https://risu.org.ua/ua/index/exclusive/kaleidoscope/64136/ (in Ukrainian).

Pope Francis (2013). Encyclical Lumen Fidei. Retrieved from http://oranta.org/index. php?id=1342\&ltemid=58\&option=com content\&task= view (in Ukrainian).

Pope Francis (2020). Encyclical "All the Brothers" on brotherhood and social friendship. Retrieved from https://jesuits.org.ua/wp-content/uploads/2020/12/FRATELLITUTTI.pdf (in Ukrainian).

Pope Leo XIII (2015). Encyclical «Rerum Novarum» (1891). Retrieved from http://irs.ucu.edu.ua/dzherela/sotsialnientsikliki/lev-xiii-rerum-novarum-1891/(in Ukrainian).

Pope Pius XII (2021). Encyclical Summi Pontificatus (1939). Retrieved from http://christking.com.ua/enciklika-piya-xiisummi-pontificatus-1939-r/.

Prodan, T. (2016) Human dignity and religious freedom in the context of post-secular dialogue. Religious freedom at the crossroads of epochs, countries and civilizations, 19: 66-69. Retrieved from https://uars.info/prints/rs/19/19.pdf (in Ukrainian).

Relihiya v Ukrayini (2012, Februari, 21) Vinnytske «Vikno zhyttya» pry monastyri Sester-Kanosiyanok vryatuvalo dytynu. Retrieved from https://www.religion.in.ua/news/ukrainian news/14725-vinnicke-vikno-zhittya-primonastiri-sester-kanosiyanok-vryatuvalo-ditinu.html Ukrainian).

RISU (2019). A social center for single mothers has been opened in Kharkiv Region. Retrieved from https://risu.org.ua/ua/index/all news/community/charity/77544/ Ukrainian).

RISU (2019). Religious organizations in Ukraine (as of January 1 , 2019). Retrieved from https://risu.org.ua/ua/index/resourses/statistics/ukr 2019/75410/ (in Ukrainian).

Strack, C. (2015, September, 10). Kommentariy: pomoshch bezhentsam - missiya khristian (Helping refugees - Christian mission). Deutsche Welle. Retrieved from https://clck.ru/TR3Uz (in Russian).

Vasilevich, N. (2019, October, 29). Lyubov k blizhnemu: kak khristianskiye tserkvi Germanii pomogayut bezhentsam [Love of neighbor: how the Christian churches of Germany help refugees]. DEKODER GGMBH. Retrieved from https://www.dekoder.org/ru/gnose/hristianskie-cerkvigermanii-bezhenci (in Russian).

Yarotskyi, P. (2011). European integration or Euro reChristianization (or synthesis of secular and sacred). Ukraine and the Vatican. A series of collections of scientific works. V. IV: State-Church Relations in the Context of the Experience of a United Europe: 8-15 (in Ukrainian).

Анна Лапутько,

Національний медичний університет імені О. О. Богомольия (Київ, Украӥна)

e-mail: belogortseva@ukr.net,ORCID:0000-0002-7501-500X

\section{КОНЦЕПЦІЯ ЛЮДСЬКОЇ ГІДНОСТІ ЯК ОСНОВА СПІВПРАЦІ КАТОЛИЦЬКОЇ ЦЕРКВИ ДЕРЖАВНИМИ ТА ГРОМАДСЬКИМИ ОРГАНІЗАЦІЯМИ}

В статті досліджується осмислення концепції людської гідності у католицькій соціальній доктрині та світських правових деклараціях, спрямованих на захист прав особистості. Показується, що, незважаючи на суттєві базові засновки, концепція гідності людини є основоположною у вирішенні новітніх соціаль- 
них проблем. Людська гідність, в такий спосіб, являється основою плідного діалогу між Католицькою церквою та світом 3 метою створення суспільства миру, поваги та благополуччя. Доводиться, що поворот до систематичного використання мови прав людини та стратегій захисту гідності особистості відбувся під час Другого Ватиканського собору. Даний процес $є$ частиною антропологічного повороту християнства у межах глобальних трансформацій релігійного світогляду в епохи пізнього модерну і постмодернізму. Оновлення соціального вчення католицизму відбувається у межах останньої енцикліки «Fratelli tutti» папи Франциска. Головним для соціального вчення енцикліки «Fratelli tutti» папи Франциска стає принцип абсолютної цінності гідності людської особистості. Цей принцип всебічно обґрунтовується. Папа визнає, що для сьогоднішнього соціального дискурсу абсолютність гідності людської особистості неочевидна, особистість все більше редукується до індивідууму, яким можна маніпулювати, знищуючи природний контекст життя, яким для особистості завжди були спільноти. Папа надає аргументи щодо гідності особистості, які відкриваються через віру, любов, рефлексію та соціальний діалог.

Ключові слова: людська гідність; Католицька церква; образ Божий; документи Другого ватиканського собору; Загальна декларація прав людини.

(c) Anna Laputko

Надійшла до редакції: 28.12.2020

Прийнята до друку: 04.02.2021 